\title{
Importance of antenatal blood group typing and antibody screening in non-ABO/Rh haemolytic disease of the newborn
}

\section{Dear Editor,}

Haemolytic disease of the fetus and newborn (HDFN) is a severe, potentially fatal alloimmune condition where maternal antibodies are produced, transported across the placenta and react against fetal red blood cell (RBC) antigens, resulting in varying degrees of haemolytic anaemia. Although $\mathrm{ABO}$ and Rhesus D $(\mathrm{RhD})$ incompatibility is responsible for the majority of cases, antibodies directed against other Rh antigens and blood group systems have the potential to cause severe HDFN. In this report, we present 2 cases of severe HDFN due to maternal alloantibodies directed against non-RhD red cell antigens that were not identified antenatally (Table 1).

Case 1. A child of Indian ethnicity was delivered at $34+6$ weeks via emergency caesarean section (CS). He was noted to be cyanosed with a weak cry and was intubated at birth. Physical examination revealed gross abdominal distension with ascites, limb and scrotal oedema. A full blood count (FBC) showed anaemia with a haemoglobin $(\mathrm{Hb})$ level of $8 \mathrm{~g} / \mathrm{dL}$ and reticulocytosis of $19 \%$.

A maternal type and screen performed at 10 weeks of pregnancy showed Group $\mathrm{O} \mathrm{RhD}$ positive blood type and a negative antibody screen. However, the repeat maternal antibody screen performed just prior to delivery returned positive. Maternal red cell antibodies were identified as Anti-M alloantibodies. The paternal red cell phenotype was $M$ antigen positive. The antibodies responsible for HDFN in this child were attributed to maternal Anti-M alloantibodies.

The child typed Group $\mathrm{O}$ RhD positive and had a strongly positive direct Coombs test (DCT). In view of rapidly rising serum bilirubin levels $(173 \mu \mathrm{mol} / \mathrm{L}$ by Day 4), double volume exchange transfusion with Group O, M-antigen negative blood was performed. The child recovered well with an improvement in serum bilirubin and $\mathrm{Hb}$ with a negative DCT by Day 7 of life.

Case 2. An infant boy was transferred to our institution from a private hospital for pallor at 20 hours of life. He was of Spanish, Greek, and British descent. The pregnancy was uneventful until 36 weeks when an antenatal scan showed fetal cardiomegaly and right heart dilation. In view of non-reassuring fetal status, the child was delivered via emergency $\mathrm{CS}$. He was intubated and required external cardiac massage at birth. The first postnatal FBC showed severe anaemia ( $\mathrm{Hb} 4.5 \mathrm{~g} / \mathrm{dL})$ and jaundice (serum bilirubin $217 \mu \mathrm{mol} / \mathrm{L}$ ).

Previous maternal blood typing had been performed earlier in pregnancy, which returned as Group A RhD positive. Notably, a maternal red cell antibody screen had not been sent. An antibody screen sent from the mother upon transfer of the child returned as positive. Maternal red cell antibodies were identified as anti-RhE and anti-Rhc alloantibodies.

The child typed Group A RhD positive and had a strongly positive DCT. His serum bilirubin continued

Table 1. Summary of the 2 cases of haemolytic disease of the fetus and newborn

\begin{tabular}{|c|c|c|c|c|c|c|}
\hline Case & Child's Blood Group & $\begin{array}{c}\text { Maternal Blood } \\
\text { Group }\end{array}$ & $\begin{array}{c}\text { Maternal } \\
\text { Red Cell } \\
\text { Alloantibodies }\end{array}$ & Presentation & $\begin{array}{c}\text { Treatment } \\
\text { Administered }\end{array}$ & Complications \\
\hline 1 & Group O RhD positive & $\begin{array}{l}\text { Group O RhD } \\
\text { positive }\end{array}$ & Anti-M & $\begin{array}{l}\text { Severe anaemia, } \\
\text { pathological } \\
\text { jaundice, hydrops } \\
\text { fetalis }\end{array}$ & $\begin{array}{l}\text { Intense phototherapy, } \\
\text { packed red cells } \\
\text { transfusion, double } \\
\text { volume exchange } \\
\text { transfusion }\end{array}$ & Nil \\
\hline 2 & Group A RhD positive & $\begin{array}{l}\text { Group A RhD } \\
\text { positive }\end{array}$ & $\begin{array}{l}\text { Anti-RhE } \\
\text { Anti-Rhc }\end{array}$ & $\begin{array}{l}\text { Severe anaemia, } \\
\text { pathological } \\
\text { jaundice, high } \\
\text { output cardiac } \\
\text { failure, hydrops } \\
\text { fetalis }\end{array}$ & $\begin{array}{l}\text { Intense phototherapy, } \\
\text { intravenous } \\
\text { immunoglobulin, } \\
\text { packed red cells } \\
\text { transfusion, double } \\
\text { volume exchange } \\
\text { transfusion }\end{array}$ & $\begin{array}{l}\text { Residual liver } \\
\text { disease and hepatic } \\
\text { dysfunction }\end{array}$ \\
\hline
\end{tabular}


to rise to a peak of $339 \mu \mathrm{mol} / \mathrm{L}$ on Day 5 of life despite intense phototherapy and he underwent a double volume exchange transfusion with Group $\mathrm{O}, \mathrm{RhE}$ and Rhc antigen-negative blood. The child's $\mathrm{Hb}$ and serum bilirubin levels stabilised post-exchange transfusion. $\mathrm{He}$ developed residual hepatic dysfunction as a consequence of the massive haemolysis and hepatopathy in his first week of life, and continued to have conjugated hyperbilirubinemia with transaminitis that persisted until 7 months of age.

Discussion. Alloantibodies to non-RhD red cell antigens occur in approximately $1.5-2.5 \%$ of pregnancies. ${ }^{1}$ The most common non-RhD antibodies that have been reported to cause HDFN include anti-K, anti-Rhc and anti-RhE, with higher antibody titres being more predictive of severe fetal anaemia. ${ }^{2}$

Both of our cases presented with hydrops fetalis, the most severe form of HDFN. Hydrops fetalis manifests with two or more of the following - skin oedema, ascites, and pericardial or pleural effusion. Both had severe haemolysis resulting in significant jaundice requiring double volume exchange transfusions. High levels of unconjugated bilirubin can have serious consequences including bilirubin encephalopathy and kernicterus.

The maternal antibodies responsible for HDFN in Case 1 were anti-M alloantibodies. Interestingly, anti-M rarely causes fetal anaemia as it is typically IgM which does not cross the placenta. A case series from China reported 3 pregnant women with anti-M antibodies whose infants developed severe HDFN and required several intrauterine and postnatal transfusions. Asians, especially those with Chinese or Japanese ancestry, appear to be prone to developing HDFN due to anti-M antibodies. ${ }^{3}$

In Case 2, maternal anti-RhE and anti-Rhc alloantibodies were responsible for the development of HDFN. It has been noted that $22.6 \%$ of infants born to mothers with anti-RhE alloantibodies developed moderate to severe HDFN. ${ }^{4}$ Anti-Rhc antibodies can result in severe consequences, with intrauterine transfusions required in $17 \%$ and deaths in $10 \%$ of affected cases. ${ }^{5}$ It is important to note that the administration of anti-RhD immune globulin in pregnant mothers to reduce the risk of anti-RhD mediated HDFN does not confer protection against the development of non-RhD antibodies.

Our two cases demonstrate the ability of nonRhD antibodies to cause severe HDFN. As such, the importance of red cell antibody screening in pregnant mothers cannot be emphasised enough. If the maternal antibody screen returns as positive, further evaluation should include antibody identification and determination of the antibody titre for clinically significant antibodies. A significant titre is generally accepted to be 1:16 or higher. ${ }^{6}$ Further testing to determine fetal antigen status is recommended, including paternal testing. The prognosis of pregnancies complicated by alloimmunisation has improved significantly given the availability of fetal assessment and intrauterine transfusions. Postnatal transfusion decisions for both mothers and infants also need to be guided by the maternal antibody status in order to provide antigen negative blood.

In this report, we present two cases of severe HDFN caused by maternal red cell antibodies that were not identified antenatally due to the lack of timely maternal antibody screening. We recommend that screening should be done twice during pregnancy - at booking and at 28 weeks. $^{7}$ Our first case clearly demonstrates that a negative antibody screen in early pregnancy does not assure that it will continue to be negative later in pregnancy. In conclusion, primary prevention is key to detecting the presence of any clinically significant maternal alloantibodies to identify pregnancies at risk of developing HDFN.

\section{REFERENCES}

1. ACOG Practice Bulletin No. 192: Management of Alloimmunization during Pregnancy. Obstetrics \& Gynecology. 2018;131:e82-90.

2. Judd WJ. Practice guidelines for prenatal and perinatal immunohematology, revisited. Transfusion 2001;41:1445-52.

3. Li S, Mo C, Huang L, et al. Hemolytic disease of the fetus and newborn due to alloanti-M: three Chinese case reports and a review of the literature. Transfusion 2019;59:385-95.

4. Moran P, Robson SC, Reid MM. Anti-E in pregnancy. BJOG: An International Journal of Obstetrics and Gynaecology. 2005;107:1436-8.

5. Snowise S, Moise KJ Jr. Haemolytic Disease of the Fetus and Newborn. In: Fetal Medicine, 3rd ed. Pandya P, Wapner R, Oepkes D, et al. (Eds). Elsevier; 2020.

6. Cacciatore A, Rapiti S, Carrara S, et al. Obstetric management in Rh alloimmunizated pregnancy. J Prenat Med 2009;3:25-7.

7. Royal College of Obstetricians \& Gynaecologists. Red Cell Antibodies during Pregnancy, The Management of Women with (Green-top Guideline No. 65), 28 May 2014. Available at: https:/www.rcog.org. uk/en/guidelines-research-services/guidelines/gtg65/. Accessed on 9 June 2020

Carin Lin Yan Loh, ${ }^{1,2}{ }_{M B B S}\left(S^{\prime}\right.$ pore),

Joyce Ching Mei Lam, ${ }^{1}$ MMed (Paeds), MRCPCH (UK), FRCPA

${ }^{1}$ Paediatric Haematology / Oncology Service, KK Women's and Children's Hospital, Singapore

${ }^{2}$ Ministry of Health Holdings, Singapore

Correspondence: Dr Joyce Lam Ching Mei, KK Women's and Children's Hospital, 100 Bukit Timah Road, Singapore 229899.

Email: Joyce.Lam.C.M@singhealth.com.sg 